\title{
Genetic parameters of coagulation properties, milk yield, quality, and acidity estimated using coagulating and noncoagulating milk information in Brown Swiss and Holstein-Friesian cows
}

\author{
A. Cecchinato, M. Penasa, M. De Marchi, L. Gallo, G. Bittante, and P. Carnier ${ }^{1}$ \\ Department of Animal Science, University of Padova, viale dell'Università 16, 35020 Legnaro (PD), Italy
}

\begin{abstract}
The aim of this study was to estimate heritabilities of rennet coagulation time $(\mathrm{RCT})$ and curd firmness $\left(\mathrm{a}_{30}\right)$ and their genetic correlations with test-day milk yield, composition (fat, protein, and casein content), somatic cell score, and acidity ( $\mathrm{pH}$ and titratable acidity) using coagulating and noncoagulating (NC) milk information. Data were from 1,025 Holstein-Friesian (HF) and 1,234 Brown Swiss (BS) cows, which were progeny of $54 \mathrm{HF}$ and $58 \mathrm{BS}$ artificial insemination sires, respectively. Milk coagulation properties (MCP) of each cow were measured once using a computerized renneting meter and samples not exhibiting coagulation within 31 min after rennet addition were classified as NC milk. For NC samples, RCT was unobserved. Multivariate analyses, using Bayesian methodology, were performed to estimate the genetic relationships of RCT or $\mathrm{a}_{30}$ with the other traits and statistical inference was based on the marginal posterior distributions of parameters of concern. For analyses involving RCT, a right-censored Gaussian linear model was used and records of $\mathrm{NC}$ milk samples, being censored records, were included as unknown parameters in the model implementing a data augmentation procedure. Rennet coagulation time was more heritable [heritability $\left(\mathrm{h}^{2}\right)=0.240$ and $\mathrm{h}^{2}$ $=0.210$ for $\mathrm{HF}$ and BS, respectively] than $\mathrm{a}_{30}\left(\mathrm{~h}^{2}=\right.$ 0.148 and $h^{2}=0.168$ for HF and BS, respectively). Milk coagulation properties were more heritable than a single test-day milk yield $\left(\mathrm{h}^{2}=0.103\right.$ and $\mathrm{h}^{2}=0.097$ for $\mathrm{HF}$ and BS, respectively) and less heritable than milk composition traits whose heritability ranged from 0.275 to 0.275 , with the only exception of fat content of BS milk $\left(h^{2}=0.108\right)$. A negative genetic correlation, lower than -0.85 , was estimated between RCT and $\mathrm{a}_{30}$ for both breeds. Genetic relationships of MCP with yield and composition were low or moderate and favorable. The genetic correlation of somatic cell score with RCT
\end{abstract}

Received October 8, 2010

Accepted April 15, 2011.

${ }^{1}$ Corresponding author: paolo.carnier@unipd.it in BS cows was large and positive and even more positive were those of $\mathrm{RCT}$ with $\mathrm{pH}$ and titratable acidity in both breeds, ranging from 0.80 to 0.94 . Including $\mathrm{NC}$ milk information in the data affected the estimated correlations and decreased the uncertainty associated with the estimation process. On the basis of the estimated heritabilities and genetic correlations, enhancement of MCP through selective breeding with no detrimental effects on yield and composition seems feasible in both breeds. Milk acidity may play a role as an indicator trait for indirect enhancement of MCP.

Key words: dairy cattle, milk coagulation property, noncoagulating milk, genetic parameter

\section{INTRODUCTION}

The fraction of milk used for cheese making is growing worldwide. In Italy, the national milk yield was 11.3 million tonnes in 2008, with a quota of $93 \%$ delivered to dairies (ISTAT, 2008). More than 1 million tonnes of cheese were obtained, and approximately $45 \%$ of this amount was represented by hard and mediumhard cheeses (ISTAT, 2008). Under this scenario, milk coagulation properties (MCP), commonly measured as rennet coagulation time (RCT, min) and curd firmness $\left(\mathbf{a}_{\mathbf{3 0}}, \mathbf{m m}\right)$, become relevant for the national dairy industry. Several authors assessed the influence of MCP on cheese yield and quality (Aleandri et al., 1989; Wedholm et al., 2006), and investigated across-breed variation of MCP (Chiofalo et al., 2000; Auldist et al., 2002, 2004; De Marchi et al., 2007).

Recently, estimates of heritability for MCP, using measurements provided by computerized renneting meters, have been reported (Ikonen et al., 2004; Tyrisevä et al., 2004; Cassandro et al., 2008). Measurement of MCP on a large scale are difficult because of the high economic and time costs of laboratory analyses. Mid-infrared spectroscopy has been considered as a possible option to overcome these issues, but its ability to predict MCP of individual milk samples is questionable (Dal Zotto et al., 2008; De Marchi et al., 2009). However, mid-infrared spectroscopy predictions of in- 
dividual MCP may play a role as indicator traits in selective breeding to enhance MCP (Cecchinato et al., 2009). Enhancement of MCP through selective breeding seems to be feasible, but comprehensive information on genetic variation and relationships with traits included in current breeding goals of dairy cattle populations is needed.

The presence of noncoagulating (NC) milk samples, which occur when the timeframe to detect the coagulation event is restricted to a certain time (e.g., $31 \mathrm{~min}$ for the computerized renneting meter), is a peculiarity of MCP measurement. The occurrence of NC milk has a direct effect on the economic outcome of the cheese industry, primarily because of its effects on cheese production (Ikonen et al., 1999b) and loss of cheese yield (Okigbo et al., 1985a,b). Across-breed variation in incidence of NC milk is large. The prevalence of $\mathrm{NC}$ milk has been reported to be $1.3 \%$ in Finnish HolsteinFriesian (HF; Tyrisevä et al., 2004), 3\% in Swedish Red and White, Swedish Holstein and Danish HolsteinFriesian cattle (Wedholm et al., 2006), 4\% in Italian Brown Swiss (BS; Cecchinato et al., 2009), and 9.7\% in Italian Holstein-Friesian cattle (Cassandro et al., 2008), and to range from 8.6 (Tyrisevä et al., 2004) to $13 \%$ (Ikonen et al., 2004) in Finnish Ayrshire. Besides effects exerted by milk SCC, genetic polymorphisms of milk proteins, $\mathrm{pH}$, and chymosin concentration, genetic aspects of animals may play a role as sources of variation of NC milk incidence. In the Finnish Ayrshire cattle breed, Ikonen et al. (1999a) observed variation across sire families in the proportion of daughters producing NC milk, suggesting that noncoagulation might partly depend upon additive genetic effects.

Although noncoagulation is a relevant piece of information when assessing the coagulation ability of milk, studies investigating variation of MCP with standard linear models (e.g., Ikonen et al., 1999a, 2004; Tyrisevä et al., 2004; Cassandro et al., 2008) did not make use of NC samples because of missing information on coagulation time. Alternatively, NC samples have been considered when the analysis was based on a different trait definition (e.g., occurrence of coagulation of milk; Tyrisevä et al., 2003), which involves categorization on the binary scale, albeit this method suffers from a severe information loss (Kotsiantis and Kanellopoulos, 2006). Both approaches are suboptimal with regard to data peculiarities. In the first case, samples of milk with very unsatisfactory MCP are omitted from the analysis, biasing the estimation of location and dispersion parameters for MCP. In the second case, milk samples differing in the time of curd formation after rennet addition are treated alike and continuous variation of coagulation time for coagulated samples is inappropriately neglected. Recently, Cecchinato and
Carnier (2011) evaluated different statistical models suitable for making use of NC milk information and investigated the effects of including $\mathrm{NC}$ samples on the estimated heritabilities and sire rankings. No study has investigated the genetic relationship between MCP and other milk traits including $\mathrm{NC}$ milk information in the statistical analysis.

The aim of this study was to estimate genetic parameters for MCP, milk yield, composition, SCS, and acidity in $\mathrm{HF}$ and $\mathrm{BS}$ cattle using coagulating and $\mathrm{NC}$ milk information and to evaluate the effects of including $\mathrm{NC}$ milk records in the analysis on the estimated correlations.

\section{MATERIALS AND METHODS}

\section{Field Data}

Data were from 2 studies aimed at estimating genetic parameters for MCP traits in Italian HF (Cassandro et al., 2008) and evaluating MCP predictions obtained by mid-infrared spectroscopy as indicator traits in breeding programs for enhanced MCP in Italian BS cows (Cecchinato et al., 2009). A total of $1,025 \mathrm{HF}$ cows distributed in 34 herds and 1,234 BS cows distributed in 38 herds were milk-sampled (1 sample per cow) from January to July 2004 and from June 2006 to July 2007, respectively. Cows were progeny of $54 \mathrm{HF}$ and $58 \mathrm{BS}$ AI sires. Individual $10-\mathrm{mL}$ milk samples were used for measuring MCP through a computerized renneting meter (Polo Trade, Monselice, Italy) within $3 \mathrm{~h}$ after sampling, which occurred during the morning milking. Samples were heated to $35^{\circ} \mathrm{C}$ and $200 \mu \mathrm{L}$ of rennet (Hansen standard 190 with $63 \%$ of chymosin and $37 \%$ of pepsin; Pacovis Amrein AG, Bern, Switzerland) diluted to $1.6 \%$ with distilled water were added. Milk coagulation properties were measured for $31 \mathrm{~min}$ after the addition of rennet and samples not forming a curd within the testing time were classified as NC milk. For NC samples, $\mathrm{a}_{30}$ had a value of $0 \mathrm{~mm}$ and RCT was missing. Details on the measurement of RCT and $\mathrm{a}_{30}$ can be found in Dal Zotto et al. (2008). In addition to MCP, measures of milk fat, protein, and CN content, titratable acidity expressed in Soxhlet-Henkel degrees, milk pH, and SCC were available. Values of SCC were log-transformed to SCS (Ali and Shook, 1980). Pedigree information was supplied by the Italian Holstein-Friesian Cattle Breeders Association (ANAFI, Cremona, Italy) and the Italian Brown Swiss Cattle Breeders Association (ANARB, Verona, Italy), and included cows with phenotypic records for the investigated traits and all their known ancestors. Each animal with phenotypic records had at least 4 known ancestors in the pedigree data. 


\section{Statistical Analysis}

A 4-trait animal model was used to investigate the relationships between MCP, milk yield, quality, and acidity traits. Based on results of Cecchinato and Carnier (2011), a right-censored linear Gaussian model was used to estimate genetic parameters for RCT including $\mathrm{NC}$ samples in the statistical analysis. Observations on traits were analyzed as continuous variables and assumed to be sampled from the following multivariate normal distribution:

$$
\begin{array}{r}
p\left(\left[\begin{array}{c}
\mathbf{y}_{\mathrm{MCP}} \\
\mathbf{y}_{\mathrm{MQT} 1} \\
\mathbf{y}_{\mathrm{MQT} 2} \\
\mathbf{y}_{\mathrm{MQT} 3}
\end{array}\right] \mid \mathbf{b}, \mathbf{p}, \mathbf{a}, \mathbf{R}\right) \\
\sim \mathrm{MVN}\left(\left[\begin{array}{c}
\mathbf{X}_{\mathrm{MCP}}+\mathbf{Z}_{1} \mathbf{p}_{\mathrm{MCP}}+\mathbf{Z}_{\mathbf{2}} \mathbf{a}_{\mathrm{MCP}} \\
\mathbf{X}_{\mathrm{MQT1}}+\mathbf{Z}_{\mathbf{1}} \mathbf{p}_{\mathrm{MQT} 1}+\mathbf{Z}_{\mathbf{2}} \mathbf{a}_{\mathrm{MQT} 1} \\
\mathbf{X}_{\mathrm{MQT} 2}+\mathbf{Z}_{\mathbf{1}} \mathbf{p}_{\mathrm{MQT} 2}+\mathbf{Z}_{\mathbf{2}} \mathbf{a}_{\mathrm{MQT} 2} \\
\mathbf{X b}_{\mathrm{MQT} 3}+\mathbf{Z}_{\mathbf{1}} \mathbf{p}_{\mathrm{MQT} 3}+\mathbf{Z}_{\mathbf{2}} \mathbf{a}_{\mathrm{MQT} 3}
\end{array}\right], \mathbf{I} \otimes \mathbf{R}\right),
\end{array}
$$

where $\mathbf{y}_{\mathrm{MCP}}$ is a vector of phenotypic observations on RCT or $\mathrm{a}_{30}$ and $\mathbf{y}_{\mathrm{MQT} 1}$ is a vector of phenotypic observations on test-day milk yield; $\mathbf{y}_{\text {MQT2 }}$ and $\mathbf{y}_{\text {MQT3 }}$ are vectors of observations on 2 other traits, which could be protein content, fat content, $\mathrm{CN}$ content, $\mathrm{SCS}$, $\mathrm{pH}$, or titratable acidity; $\mathbf{X}, \mathbf{Z}_{1}$, and $\mathbf{Z}_{2}$ are incidence matrices relating fixed systematic $\left(\mathbf{b}^{\prime}=\left[\mathbf{b}_{\mathrm{MCP}}^{\prime} \mathbf{b}_{\mathrm{MQT1}}^{\prime} \mathbf{b}_{\mathrm{MQT2}}^{\prime} \mathbf{b}_{\mathrm{MQT3}}^{\prime}\right]\right), \quad$ random herd $\left(\mathbf{p}^{\prime}=\left[\mathbf{p}_{\mathrm{MCP}}^{\prime} \mathbf{p}_{\mathrm{MQT} 1}^{\prime} \mathbf{p}_{\mathrm{MQT} 2}^{\prime} \mathbf{p}_{\mathrm{MQT} 3}^{\prime}\right]\right)$, and random additive genetic effects $\left(\mathbf{a}^{\prime}=\left[\mathbf{a}_{\mathrm{MCP}}^{\prime} \mathbf{a}_{\mathrm{MQT1}}^{\prime} \mathbf{a}_{\mathrm{MQT} 2}^{\prime} \mathbf{a}_{\mathrm{MQT} 3}^{\prime}\right]\right)$ to the vector of observations; $\mathbf{I}$ is an identity matrix of appropriate order; and $\mathbf{R}$ is a $4 \times 4$ matrix of residual (co)variances. For milk samples that did not coagulate within the time of analysis (31 min), RCT records were treated as right-censored records and were included as unknown parameters in the model, using the methodology described by Guo et al. (2001) based on a data augmentation procedure (Tanner and Wong, 1987). The fixed systematic effects considered in $\mathbf{b}$ for both breeds were DIM class (class 1: $<50 \mathrm{~d}$, class 2: 50 to 90 d, class 3: 91 to $120 \mathrm{~d}$, class 4: 121 to $150 \mathrm{~d}$, class 5: 151 to 180 d, class 6: 181 to 220 d, class 7: 221 to $260 \mathrm{~d}$, class 8: 261 to $300 \mathrm{~d}$, class 9: 301 to $350 \mathrm{~d}$, and class 10: $>350 \mathrm{~d}$ ) and parity (class 1: first parity, class 2: second parity, class 3: third and later parities).

Flat priors were used for systematic effects and dispersion parameters. Prior distributions for the additive genetic effects in $\mathbf{a}$ and herd effects in $\mathbf{p}$ were normal densities. In a Bayesian setting, we assumed

$$
p(\mathbf{a} \mid \mathbf{A}, \mathbf{G}) \sim \operatorname{MVN}(0, \mathbf{A} \otimes \mathbf{G}),
$$

where $\mathbf{G}$ is a $4 \times 4$ additive genetic (co)variance matrix, and $\mathbf{A}$ is the numerator relationship matrix between individuals. Likewise, herd effects were assumed to follow a multivariate normal distribution:

$$
p(\mathbf{p} \mid \mathbf{I}, \mathbf{P}) \sim \operatorname{MVN}(0, \mathbf{I} \otimes \mathbf{P}),
$$

where $\mathbf{P}$ is a $4 \times 4$ herd (co)variance matrix.

To evaluate the effects of including NC milk information on the estimated correlations, all analyses were replicated after omitting $\mathrm{NC}$ milk records from the data.

Marginal posterior distributions of unknown parameters were estimated performing numerical integration through the Gibbs sampler (Gelfand and Smith, 1990), as implemented in the program TM (http://snp.toulouse.inra.fr/ alegarra). A single Gibbs chain of 500,000 samples was obtained for each multivariate model and the initial 50,000 samples were discarded as burn-in. The effective length of the burn-in and the chain size were chosen on the basis of the methods of Raftery and Lewis (1992) and Geyer (1992), respectively. Sample values were saved every 50 iterations. The posterior median was used as a point estimate of (co)variance components and related parameters. Lower and upper bounds of the $95 \%$ highest posterior probability density regions for heritabilities and additive genetic correlations were estimated from the Gibbs samples.

Heritability was computed as

$$
h^{2}=\frac{\sigma_{\mathrm{A}}^{2}}{\sigma_{\mathrm{A}}^{2}+\sigma_{\mathrm{H}}^{2}+\sigma_{\mathrm{E}}^{2}},
$$

where $\sigma_{\mathrm{A}}^{2}, \sigma_{\mathrm{H}}^{2}$, and $\sigma_{\mathrm{E}}^{2}$ are additive genetic, herd, and residual variances, respectively.

Additive genetic correlations were estimated as

$$
\mathrm{r}_{\mathrm{A}}=\frac{\sigma_{\mathrm{A} 1, \mathrm{~A} 2}}{\sigma_{\mathrm{A} 1} \cdot \sigma_{\mathrm{A} 2}},
$$

where $\sigma_{\mathrm{A} 1, \mathrm{~A} 2}$ is the additive genetic covariance between trait 1 (RCT or $\mathrm{a}_{30}$ ) and 2 (milk, SCC, or acidity traits), and $\sigma_{\mathrm{A} 1}$ and $\sigma_{\mathrm{A} 2}$ are the additive genetic standard deviations for trait 1 and 2 , respectively. 
Table 1. Descriptive statistics of single test-day milk yield, composition, acidity, and coagulation properties for Holstein-Friesian ( $\mathrm{n}=1,025$; noncoagulating milk $=9.7 \%)$ and Brown Swiss $(\mathrm{n}=1,234$; noncoagulating milk $=3.5 \%)$ cows

\begin{tabular}{lccccc}
\hline & \multicolumn{2}{c}{ Holstein-Friesian } & & \multicolumn{2}{c}{ Brown Swiss } \\
\cline { 2 - 3 } \cline { 5 - 6 } Trait $^{1}$ & Mean & CV, $\%$ & & Mean & CV, \% \\
\hline Milk yield, kg/d & 32.4 & 31 & & 28.6 & 28 \\
Milk fat, \% & 3.88 & 20 & & 3.98 & 19 \\
Milk protein, $\%$ & 3.45 & 12 & & 3.72 & 10 \\
CN, \% & 2.65 & 11 & & 2.88 & 10 \\
SCS & 3.07 & 63 & & 2.41 & 90 \\
pH & 6.67 & 2 & & 6.69 & 2 \\
Titratable acidity, SH $^{\circ} / 50 \mathrm{~mL}$ & 3.26 & 13 & & 3.25 & 13 \\
RCT, min & 16.9 & 27 & & 15.0 & 27 \\
a $_{30}$, mm & 32.0 & 35 & & 41.7 & 21 \\
\hline
\end{tabular}

${ }^{1} \mathrm{SCS}=\log _{2}(\mathrm{SCC} / 100,000)+3 ; \mathrm{SH}^{\circ}=$ Soxhlet-Henkel degrees; RCT $=$ rennet coagulation time for milk samples that coagulated (926 samples for Holstein-Friesian and 1,191 samples for Brown Swiss cows); $\mathrm{a}_{30}=$ curd firmness for milk samples that coagulated.

\section{RESULTS AND DISCUSSION}

\section{Descriptive Statistics}

Descriptive statistics for the investigated traits are reported in Table 1. A comprehensive discussion on these traits has been reported by Cassandro et al. (2008) for HF and Cecchinato et al. (2009) for BS cows. In general, BS had more favorable milk quality features and MCP compared with HF cows. However, because sample collection was carried out in different periods and herds, the effects of breed, herd, and testing conditions might be confounded. The proportion of NC milk samples (i.e., samples that did not coagulate within the testing time of $31 \mathrm{~min}$ ) was 9.7 and $3.5 \%$ for $\mathrm{HF}$ and BS cows, respectively.

\section{Additive Genetic Variation and Heritability}

Point estimates and features of marginal posterior densities for the additive genetic standard deviation and heritability of traits are reported in Table 2. For $\mathrm{RCT}$ and $\mathrm{a}_{30}$, inference on additive genetic variation and heritability was based on the marginal posterior density estimated using pooled samples of all Gibbs chains obtained in multivariate analyses. Because of that, estimates for RCT and $\mathrm{a}_{30}$ differ, albeit being very similar in magnitude, from those obtained by Cecchinato and Carnier (2011) using univariate analyses. For HF cows, heritability estimates for RCT and $\mathrm{a}_{30}$ were comparable to those obtained for the same data by Cassandro et al. (2008) using residual or restricted maximum likelihood (REML) methodology and discarding NC milk samples. Heritability estimates for RCT and $\mathrm{a}_{30}$ in BS were very similar to those computed for HF cows. The heritability for RCT was lower than estimates obtained for Finnish Ayrshire cows using coagulated samples only (Ikonen et al., 2004). In that study, heritability for $\mathrm{a}_{30}$ was assessed through a linear model either including or omitting NC sample records from the data and considering the trait as continuous or as binary (i.e., occurrence of coagulation of milk within $31 \mathrm{~min}$ ). Including $\mathrm{NC}$ samples in the analysis of Ikonen et al. (2004) decreased the estimated heritability for $\mathrm{a}_{30}$ from 0.39 to 0.22 (continuous scale) and to 0.26 (binary scale). In the present study, the estimated additive genetic standard deviation of RCT was $36 \%$ greater for $\mathrm{HF}$ than for $\mathrm{BS}$ cows. The larger variability detected for RCT in HF cows is related to the greater proportion of NC samples compared with BS cows. In a standard linear model, records that do not exhibit coagulation within the time of analysis are removed from the data. For such samples, the Markov chain Monte Carlo procedure generated augmented records that were sampled from a truncated distribution with values greater than the censoring time (31 $\mathrm{min})$. The rationale is that a sample of milk may need more than 31 min to coagulate. This suggests that statistical analyses omitting NC samples records are likely to underestimate the actual variation of the trait. Cassandro et al. (2008) reported, for HF cows, an estimated additive genetic standard deviation of $2.22 \mathrm{~min}$ and $4.06 \mathrm{~mm}$ for RCT and $\mathrm{a}_{30}$, respectively, using a multiple-trait linear model and excluding $\mathrm{NC}$ samples from the analysis. For RCT, the estimated additive genetic variation was remarkably lower than that obtained in our study using $\mathrm{NC}$ milk information.

The probability that the heritability of a single testday milk record was greater than 0.10 was estimated to be 0.53 . The heritability for single test-day milk yield in Finnish Ayrshire (Ikonen et al., 2004) was slightly larger than estimates obtained in the present study. For the same trait, Samoré et al. (2007) used a large set of 
Table 2. Features of marginal posterior densities of additive genetic standard deviation $\left(\sigma_{\mathrm{A}}\right)$ and heritability $\left(\mathrm{h}^{2}\right)$ for the investigated traits in Holstein-Friesian and Brown Swiss cows ${ }^{1}$

\begin{tabular}{|c|c|c|c|c|c|c|c|c|c|c|}
\hline \multirow{2}{*}{ Trait $^{2}$} & \multicolumn{5}{|c|}{ Holstein-Friesian } & \multicolumn{5}{|c|}{ Brown Swiss } \\
\hline & \multicolumn{2}{|c|}{$\sigma_{\mathrm{A}}$} & \multicolumn{3}{|c|}{$h^{2}$} & \multicolumn{2}{|c|}{$\sigma_{\mathrm{A}}$} & \multicolumn{3}{|c|}{$h^{2}$} \\
\hline $\mathrm{RCT}, \min$ & 3.158 & $2.22,4.63$ & 0.240 & $0.22,0.58$ & 0.99 & 2.322 & $1.76,2.90$ & 0.210 & $0.12,0.32$ & 1.00 \\
\hline $\mathrm{a}_{30}, \mathrm{~mm}$ & 4.408 & $2.46,6.63$ & 0.148 & $0.05,0.32$ & 0.79 & 4.586 & $3.17,5.87$ & 0.168 & $0.08,0.27$ & 0.91 \\
\hline Milk yield, $\mathrm{kg} / \mathrm{d}$ & 2.492 & $1.42,3.70$ & 0.103 & $0.03,0.22$ & 0.53 & 2.042 & $1.02,2.94$ & 0.097 & $0.02,0.19$ & 0.53 \\
\hline $\mathrm{CN}, \%$ & 0.166 & $0.13,0.22$ & 0.364 & $0.22,0.58$ & 1.00 & 0.134 & $0.10,0.17$ & 0.275 & $0.16,0.41$ & 1.00 \\
\hline SCS & 0.733 & $0.43,1.06$ & 0.136 & $0.05,0.27$ & 0.76 & 0.692 & $0.44,0.93$ & 0.090 & $0.04,0.17$ & 0.41 \\
\hline pH & 0.047 & $0.03,0.06$ & 0.188 & $0.09,0.34$ & 0.97 & 0.040 & $0.03,0.05$ & 0.058 & $0.03,0.10$ & 0.03 \\
\hline $\mathrm{TA}, \mathrm{SH}^{\circ} / 50 \mathrm{~mL}$ & 0.202 & $0.14,0.28$ & 0.230 & $0.11,0.42$ & 0.99 & 0.189 & $0.14,0.24$ & 0.190 & $0.11,0.30$ & 0.98 \\
\hline
\end{tabular}

${ }^{1}$ Median = median of the marginal posterior density of the parameter; HPD95\% = lower and upper bound of the $95 \%$ highest posterior density region; $P\left(\mathrm{~h}^{2}>0.10\right)=$ posterior probability of heritability being greater than 0.10 .

${ }^{2} \mathrm{RCT}=$ rennet coagulation time; $\mathrm{a}_{30}=$ curd firmness; milk yield $=$ test-day milk yield; TA $=$ titratable acidity (Soxhlet-Henkel degrees).

BS data and estimated a heritability of 0.10 using a test-day repeatability animal model. In agreement with Ikonen et al. (2004), heritability estimates for RCT and $\mathrm{a}_{30}$ in both breeds were greater than the estimated heritability for test-day milk yield.

Estimates of heritability for fat and protein contents in HF were slightly lower than those obtained by Ikonen et al. (1999a) for Finnish HF cows. Heritabilities of protein content were similar for BS and HF cows, but those of fat content differed greatly between breeds. Estimates for protein and fat content in BS were similar to those obtained by Samoré et al. (2007) for BS cows and repeated test-day records. Ikonen et al. (2004) estimated a heritability of 0.29 for single test-day protein content and 0.18 for fat content in the Finnish Ayrshire population. Comparable estimates for single test-day fat and protein content were also reported by Tyrisevä et al. (2004).

The heritability of $\mathrm{CN}$ content for $\mathrm{HF}$ cows was comparable to estimates by Ikonen et al. (2004) and Samoré et al. (2007) and greater than the estimate for BS cows. For SCS, heritability estimates were slightly higher than those reported by Ikonen et al. (2004) and Samoré et al. (2007), but they were very similar to estimates from Ikonen et al. (1999a). The heritability of milk acidity traits had a probability larger than 0.95 of being greater than 0.10 , with the only exception being the estimate for $\mathrm{pH}$ in $\mathrm{BS}$ cows. Larger estimated heritabilities for $\mathrm{pH}$ have been reported by Ikonen et al. (1999a, 2004), whereas Tyrisevä et al. (2004) estimated a heritability of 0.18 . Factors which might explain inconsistencies across studies for the estimated heritabilities include breed, procedures and conditions for trait recording, model, and method of estimation. To our knowledge, no $\mathrm{pH}$ heritability estimates are currently available for BS cattle to compare our estimate with.

\section{Genetic Correlations}

Features of marginal posterior densities of additive genetic correlations of RCT with $\mathrm{a}_{30}$, milk yield and composition, SCS, and milk acidity are presented in Table 3 . For both breeds, RCT and $\mathrm{a}_{30}$ were tightly and negatively correlated. Likewise, Ikonen et al. (2004) reported that RCT and $\mathrm{a}_{30}$ were genetically closely correlated in Finnish Ayrshire cows. A genetic relationship between RCT and $\mathrm{a}_{30}$ of -0.89 was estimated, omitting the NC milk information and based on REML procedures, for the same HF data used in this study (Cassandro et al., 2008). Tight and negative relationships between RCT and $\mathrm{a}_{30}$ are expected because these traits are measured in consecutive steps of the milk coagulation process and the timeframe for the assessment of MCP is restricted to $31 \mathrm{~min}$. Milk samples exhibiting delayed coagulation have less time, relative to fast-coagulating milk, for curd firming and, as a consequence, lower average values for $\mathrm{a}_{30}$. The genetic correlation between RCT and $\mathrm{a}_{30}$ obtained using BS data was less negative than that obtained for HF. Likely, this result is to be attributed to the lower average RCT of BS relative to that of HF cows. Across-breed differences in the estimated correlations can be attributed to several sources of variation. One of these is differences in frequency and effects of genotypes at milk protein genes. The present study did not account for the effects of milk protein genotypes on the estimated (co) variance components because assessment of genotypes at milk protein genes was not available for BS cows. The estimated correlations and the greater heritability for RCT, relative to $\mathrm{a}_{30}$, obtained in this study suggest that the enhancement of MCP through selective breeding might require collection of individual phenotypes for RCT only. However, selection procedures based on 
direct measures of RCT phenotypes would be very hard to implement because of limitations imposed by features of the computerized renneting meter (Dal Zotto et al., 2008). The opportunity of predicting individual phenotypes for RCT using the same milk sample and equipment used for assessing fat and protein contents, with immediate availability and the only additional cost of instrumental calibration, makes infrared techniques an interesting option for large-scale RCT assessment in milk-recording programs. This has been recently investigated by Cecchinato et al. (2009) who evidenced that RCT predictions provided by infrared techniques can play a role as an indicator trait in breeding programs for the enhancement of MCP.

Point estimates of genetic correlations of RCT with milk yield or composition (percentages of fat, protein and $\mathrm{CN}$ ) were slightly or moderately negative. For all these correlations, the $95 \%$ highest posterior density region included zero and the posterior probability of being lower than -0.10 ranged from 0.50 to 0.81 for $\mathrm{HF}$ and from 0.25 to 0.52 for BS cows. These results indicate that the correlated response of milk coagulation ability to changes in yield and composition, as dictated by current breeding goals of dairy cattle populations, is expected to be limited. Also, they provide evidence of the limited role that $\mathrm{CN}$ percentage might play as an indicator trait in breeding programs aiming at enhancing RCT. Recently, milk protein composition has been reported to affect variation of MCP (Bonfatti et al., 2010).

Somatic cell score exhibited positive genetic correlations with RCT. Because current breeding goals for HF and BS populations favor low SCS, these correlations are considered desirable. For HF cows, the magnitude of the estimated correlation was moderate, but it was larger for BS cows. For this breed, the $95 \%$ highest pos- terior density region of the correlation ranged from 0.26 to 0.87 and the estimate exhibited a posterior probability of being greater than 0.10 that was practically 1. The estimated genetic correlation between RCT and SCS in HF cows was comparable to that obtained by Cassandro et al. (2008) with REML analysis omitting NC milk samples. Lindström et al. (1984) reported that RCT did not correlate with udder health traits and Ikonen et al. (2004) estimated a moderate genetic correlation between RCT and SCS.

With the exception of the relationship between $\mathrm{RCT}$ and $\mathrm{a}_{30}$, the genetic correlations of MCP with $\mathrm{pH}$ and titratable acidity were the relationships exhibiting the largest magnitude in this study, both for $\mathrm{HF}$ and BS cows. These results agree with findings of studies conducted by Lindström et al. (1984), Oloffs et al. (1992), and Tyrisevä et al. (2000). Low pH and high titratable acidity correlated with short RCT and high $\mathrm{a}_{30}$, which are desirable milk properties for cheese making. This suggests that variation in milk acidity might be exploited to enhance the coagulation ability of milk. The genetic association of RCT with $\mathrm{pH}$ was of greater magnitude for BS than for HF cows, whereas no across-breed variation was observed in the estimated correlations with titratable acidity. Although both $\mathrm{pH}$ and titratable acidity are measures of milk acidity, the magnitude of the estimated relationships of $\mathrm{pH}$ with RCT was 27 (HF) or $62 \%$ (BS) larger than that obtained for titratable acidity. For $\mathrm{pH}$, positive genetic relationships with RCT were reported also by Ikonen et al. (1999a, 2004) for Finnish Ayrshire cows, but the estimated correlations were lower than those obtained in the present study.

Features of marginal posterior densities of additive genetic correlations of $\mathrm{a}_{30}$ with milk production traits, SCS, and milk acidity are presented in Table 4 . With

Table 3. Features of the marginal posterior density of additive genetic correlations of rennet coagulation time (RCT, min) with curd firmness $\left(\mathrm{a}_{30}, \mathrm{~mm}\right)$, single test-day milk yield and composition, SCS, and milk acidity in Holstein-Friesian and Brown Swiss cows ${ }^{1}$

\begin{tabular}{|c|c|c|c|c|c|c|}
\hline \multirow{2}{*}{$\begin{array}{l}\text { Correlation } \\
\text { of RCT with }\end{array}$} & \multicolumn{3}{|c|}{ Holstein-Friesian } & \multicolumn{3}{|c|}{ Brown Swiss } \\
\hline & Median & HPD $95 \%$ & $P\left(\mathrm{r}_{\mathrm{a}}\right)$ & Median & HPD95\% & $P\left(\mathrm{r}_{\mathrm{a}}\right)$ \\
\hline $\mathrm{a}_{30}, \mathrm{~mm}$ & -0.98 & $-0.99,-0.85$ & 1.00 & -0.86 & $-0.96,-0.61$ & 1.00 \\
\hline Milk yield, $\mathrm{kg} / \mathrm{d}$ & -0.33 & $-0.81,0.27$ & 0.81 & -0.15 & $-0.68,0.37$ & 0.59 \\
\hline Fat, \% & -0.10 & $-0.54,0.39$ & 0.51 & 0.01 & $-0.50,0.52$ & 0.36 \\
\hline Protein, \% & -0.11 & $-0.51,0.39$ & 0.50 & -0.02 & $-0.38,0.35$ & 0.35 \\
\hline $\mathrm{CN}, \%$ & -0.26 & $-0.66,0.23$ & 0.75 & -0.11 & $-0.44,0.25$ & 0.52 \\
\hline SCS & 0.25 & $-0.43,0.79$ & 0.64 & 0.62 & $0.26,0.87$ & 1.00 \\
\hline $\mathrm{pH}$ & 0.80 & $0.39,0.96$ & 1.00 & 0.94 & $0.69,0.99$ & 1.00 \\
\hline $\mathrm{TA}, \mathrm{SH}^{\circ} / 50 \mathrm{~mL}$ & -0.63 & $-0.90,-0.15$ & 1.00 & -0.58 & $-0.81,-0.21$ & 1.00 \\
\hline
\end{tabular}

${ }^{1}$ Median = median of the marginal posterior density of the parameter; HPD95\% = lower and upper bounds of the $95 \%$ highest posterior density region; $P\left(\mathrm{r}_{\mathrm{a}}\right)=$ marginal posterior probability of the additive genetic correlation being greater than 0.10 (for positive correlations) or lower than -0.10 (for negative correlations).

${ }^{2} \mathrm{TA}=$ titratable acidity (Soxhlet-Henkel degrees). 
a limited number of exceptions, the estimated genetic relationships of $\mathrm{a}_{30}$ with the other traits were, in comparison with estimates obtained for RCT, of similar magnitude and reverse sign. This is attributed to the very large negative genetic correlation between RCT and $\mathrm{a}_{30}$. Exceptions were the correlations of $\mathrm{a}_{30}$ with $\mathrm{CN}$ and protein content for $\mathrm{HF}$ and with fat percentage for BS cows, which were of greater magnitude than those for $\mathrm{RCT}$, and the estimated relationship with $\mathrm{pH}$ for BS cows that was of smaller magnitude relative to that obtained for RCT. The importance of $\mathrm{CN}$ percentage in affecting $\mathrm{a}_{30}$ variation has been reported and discussed by many authors (Pagnacco and Caroli, 1987; Summer et al., 1999; Malacarne et al., 2006).

Low SCS was correlated with high $a_{30}$, which is desirable in terms of cheese making (Table 4). Politis and Ng-Kwai-Hang (1988) reported that variation of SCC had a marked effect on MCP and Tyrisevä et al. (2000) estimated favorable genetic correlations between $\mathrm{a}_{30}$ and SCC. A possible explanation is that increased $\mathrm{SCC}$ is associated with increased plasmin activity. The accumulation of plasmin degradation products might also affect coagulation, because these components interfere with the aggregating micelles responsible for curd formation (Politis and Ng-Kwai-Hang, 1988). Plasmin can rapidly cleave both $\beta-\mathrm{CN}$ into $\gamma-\mathrm{CN}$ and smaller polypeptides (Auldist et al., 1996) and as1- and as2-CN (Le Bars and Gripon, 1993; McSweeney et al., 1993). Increased plasmin activity is a major factor for impaired coagulation features and $\mathrm{CN}$ degradation (Lucey, 1996; Srinivasan and Lucey, 2002). As reported by Zachos et al. (1992), increased plasmin activity leads to decreased cheese yield and changes in functionality of milk proteins that affect coagulation.

Curd firmness exhibited tight relationships with milk acidity traits (Table 4). Okigbo et al. (1985a) reported that $\mathrm{a}_{30}$ decreased when $\mathrm{pH}$ increased and, generally, milk samples did not coagulate when $\mathrm{pH}$ was greater than 6.85. Other findings (Ikonen et al., 2004) indicate that $\mathrm{pH}$ changes exert significant effects on $\mathrm{a}_{30}$. Changes in $\mathrm{pH}$ are known to affect enzyme activity (Okigbo et al., 1985a). Nielsen (2003) evidenced that plasmin is less active in low-pH milk. Because associations among SCS, $\mathrm{pH}$, and plasmin activity exist, recursive relations between these traits, which was not possible to disentangle in this study, can be envisaged.

In the present study, genetic parameters were estimated without considering that animals came from populations selected on milk traits. Even though selection was not directly performed on MCP and milk acidity, a correlated response is expected and some sources of inaccuracy in the estimation procedure associated with selection might have occurred. In this study, such a problem was alleviated by including test-day milk yield in the multivariate analysis.

The effects of including NC milk information on the estimated correlations were evaluated by comparing estimates and features of posterior densities of parameters obtained under the censored Gaussian linear model with those provided by a standard linear model fitted after NC samples records were omitted from the data (results not presented in tables). Such effects were not trivial. Including NC milk information affected the estimated correlations and decreased the uncertainty associated with the estimation process. The range of the $95 \%$ highest posterior density regions markedly decreased when NC milk records were included in the analysis. These effects were larger for HF than for BS estimates and they have to be ascribed to across-breed differences in the incidence of $\mathrm{NC}$ milk. As an example, the estimated correlation of RCT with $\mathrm{pH}$ for BS cows obtained with the standard linear model was 0.78 and the $95 \%$ highest posterior density region ranged from 0.39 to 0.96 . Under the censored linear model, the point

Table 4. Features of the marginal posterior density of additive genetic correlations of curd firmness $\left(\mathrm{a}_{30}, \mathrm{~mm}\right)$ with single test-day milk yield and composition, SCS, and milk acidity in Holstein-Friesian and Brown Swiss cows $^{1}$

\begin{tabular}{|c|c|c|c|c|c|c|}
\hline \multirow{2}{*}{$\begin{array}{l}\text { Correlation } \\
\text { of } a_{30} \text { with }^{2} \\
\end{array}$} & \multicolumn{3}{|c|}{ Holstein-Friesian } & \multicolumn{3}{|c|}{ Brown Swiss } \\
\hline & Median & HPD95\% & $P\left(\mathrm{r}_{\mathrm{a}}\right)$ & Median & HPD95\% & $P\left(\mathrm{r}_{\mathrm{a}}\right)$ \\
\hline Milk yield, $\mathrm{kg} / \mathrm{d}$ & 0.32 & $-0.27,0.86$ & 0.85 & -0.18 & $-0.65,0.38$ & 0.60 \\
\hline Fat, \% & 0.05 & $-0.48,0.58$ & 0.43 & 0.37 & $-0.25,0.75$ & 0.82 \\
\hline Protein, \% & 0.35 & $-0.33,0.78$ & 0.76 & 0.05 & $-0.39,0.44$ & 0.41 \\
\hline $\mathrm{CN}, \%$ & 0.67 & $0.01,0.85$ & 0.95 & 0.18 & $-0.26,0.53$ & 0.67 \\
\hline SCS & -0.34 & $-0.89,0.47$ & 0.72 & -0.69 & $-0.93,-0.22$ & 1.00 \\
\hline $\mathrm{pH}$ & -0.94 & $-0.99,-0.60$ & 1.00 & -0.74 & $-0.95,-0.31$ & 1.00 \\
\hline $\mathrm{TA}, \mathrm{SH}^{\circ} / 50 \mathrm{~mL}$ & 0.85 & $0.20,0.98$ & 1.00 & 0.59 & $0.22,0.80$ & 1.00 \\
\hline
\end{tabular}

${ }^{1}$ Median $=$ median of the marginal posterior density of the parameter; HPD95\% = lower and upper bounds of the $95 \%$ highest posterior density region; $P\left(\mathrm{r}_{\mathrm{a}}\right)=$ marginal posterior probability of the additive genetic correlation being greater than 0.10 (for positive correlations) or lower than -0.10 (for negative correlations).

${ }^{2} \mathrm{TA}=$ titratable acidity (Soxhlet-Henkel degrees). 
estimate of the same correlation was 0.94 (i.e., an absolute change of 0.16 ) and the $95 \%$ highest posterior density region ranged from 0.69 to 0.99 . In general and for both breeds, inclusion of NC milk information decreased the estimated correlations of RCT with the other traits relative to estimates obtained with the standard linear model. Exceptions were the genetic correlations with SCS and $\mathrm{pH}$ that, when NC milk data were included in a censored linear model, resulted in a higher estimate compared with the standard linear model. It is worth mentioning that SCS and $\mathrm{pH}$ were the only traits exhibiting large positive correlations with $\mathrm{RCT}$ in the analysis omitting NC milk records. Absolute changes of correlations between RCT and the other traits were larger for milk yield and composition than for SCS and milk acidity. Absolute changes of correlations of RCT with yield and composition traits ranged from 0.16 (milk yield) to 0.29 (protein percentage) for $\mathrm{HF}$ data and from 0.05 (fat percentage) to 0.14 (protein percentage) for BS data. For SCS and milk acidity traits, absolute changes ranged from 0.01 to 0.08 in both breeds. Changes for the correlation between RCT and $\mathrm{a}_{30}$ were trivial.

As expected on the basis of the large negative correlations between RCT and $\mathrm{a}_{30}$, changes of correlations of $\mathrm{a}_{30}$ with the other traits due to the use of $\mathrm{NC}$ milk information were opposite to those for RCT. Absolute changes of correlations for $\mathrm{a}_{30}$ were, in general, smaller than those for RCT and ranged from 0.01 to 0.08 .

\section{CONCLUSIONS}

Genetic relationships of MCP with milk yield, composition, SCS, and acidity were estimated for Italian $\mathrm{HF}$ and $\mathrm{BS}$ cattle, including information of $\mathrm{NC}$ milk. On the basis of the estimated parameters, limited effects on MCP are to be expected from selective breeding aiming at enhancing yield and contents of milk fat and protein. Because current breeding goals aim at decreasing SCS, favorable effects on RCT and $\mathrm{a}_{30}$, due to the genetic relationship between MCP and SCS, can be envisaged. Enhancement of MCP might also be pursued indirectly by exploiting the genetic relationships of milk acidity with RCT and $\mathrm{a}_{30}$. Because NC milk is a relevant piece of information for estimating parameters related to variation of MCP, inclusion of $\mathrm{NC}$ milk records in the data and use of appropriate statistical models is advisable, specifically when the prevalence of noncoagulation is large.

\section{ACKNOWLEDGMENTS}

The authors thank Milk Quality Laboratory of Veneto Agricoltura (Thiene, Italy) for milk renneting analysis, the Italian Holstein-Friesian Cattle Breeders Association (ANAFI, Cremona, Italy) and Italian Brown Swiss Cattle Breeders (ANARB, Verona, Italy) for providing pedigree information, and the Ministry of University and Scientific Research (MURST, Rome, Italy), Trento Province, and the Superbrown Consortium of Bolzano and Trento (Italy) for funding. The authors also acknowledge E. López de Maturana [Departamento de Mejora Genética Animal, Instituto Nacional de Investigación y Tecnología Agraria y Alimentaria (INIA), Madrid, Spain] for the use of the TM program and J. Casellas (Departament de Ciència Animal i dels Aliments, Universitat Autònoma de Barcelona, Bellaterra, Spain) for useful comments.

\section{REFERENCES}

Aleandri, R., J. C. Schneider, and L. G. Buttazzoni. 1989. Evaluation of milk for cheese production based on milk characteristics and Formagraph measures. J. Dairy Sci. 72:1967-1975.

Ali, A. K. A., and G. E. Shook. 1980. An optimum transformation for somatic cell concentration in milk. J. Dairy Sci. 63:487-490.

Auldist, M. J., S. Coats, B. J. Sutherland, J. J. Mayes, G. H. McDowell, and G. L. Rogers. 1996. Effects of somatic cell count and stage of lactation on raw milk composition and the yield and quality of Cheddar cheese. J. Dairy Res. 63:269-280.

Auldist, M. J., K. A. Johnston, N. J. White, W. P. Fitzsimons, and M. J. Boland. 2004. A comparison of the composition, coagulation characteristics and cheesemaking capacity of milk from Friesian and Jersey dairy cows. J. Dairy Res. 71:51-57.

Auldist, M. J., C. Mullins, B. O'Brien, B. T. O'Kennedy, and T. Guinee. 2002. Effect of cow breed on milk coagulation properties. Milchwissenschaft 57:140-143.

Bonfatti, V., G. Di Martino, A. Cecchinato, L. Degano, and P. Carnier. 2010. Effects of $\beta$ - $\kappa$-casein (CSN2-CSN3) haplotypes, $\beta$-lactoglobulin (BLG) genotypes, and detailed protein composition on coagulation properties of individual milk of Simmental cows. J. Dairy Sci. 93:3809-3817.

Cassandro, M., A. Comin, M. Ojala, R. Dal Zotto, M. De Marchi, L. Gallo, P. Carnier, and G. Bittante. 2008. Genetic parameters of milk coagulation properties and their relationships with milk yield and quality traits in Italian Holstein cows. J. Dairy Sci. 91:371-376.

Cecchinato, A., and P. Carnier. 2011. Short communication: Statistical models for the analysis of coagulation traits using coagulating and noncoagulating milk information. J. Dairy Sci. 94:3764-3769.

Cecchinato, A., M. De Marchi, L. Gallo, G. Bittante, and P. Carnier 2009. Mid-infrared spectroscopy predictions as indicator traits in breeding programs for enhanced coagulation properties of milk. J. Dairy Sci. 92:5304-5313.

Chiofalo, V., R. Maldonato, B. Martin, D. Dupont, and J.-B. Coulon. 2000. Chemical composition and coagulation properties of Modicana and Holstein cows' milk. Ann. Zootech. 49:497-503.

Dal Zotto, R., M. De Marchi, A. Cecchinato, M. Penasa, M. Cassandro, P. Carnier, L. Gallo, and G. Bittante. 2008. Reproducibility and repeatability of measures of milk coagulation properties and predictive ability of mid-infrared reflectance spectroscopy. J. Dairy Sci. 91:4103-4112.

De Marchi, M., R. Dal Zotto, M. Cassandro, and G. Bittante. 2007. Milk coagulation ability of five dairy cattle breeds. J. Dairy Sci. 90:3986-3992.

De Marchi, M., C. C. Fagan, C. P. O’Donnell, A. Cecchinato, R. Dal Zotto, M. Cassandro, M. Penasa, and G. Bittante. 2009. Prediction of coagulation properties, titratable acidity, and $\mathrm{pH}$ of bovine milk using mid-infrared spectroscopy. J. Dairy Sci. 92:423-432.

Gelfand, A. E., and A. F. M. Smith. 1990. Sampling-based approaches to calculating marginal densities. J. Am. Stat. Assoc. 85:398-409. 
Geyer, C. J. 1992. Practical Markov chain Monte Carlo. Stat. Sci. 7:473-483.

Guo, S.-F, D. Gianola, R. Rekaya, and T. Short. 2001. Bayesian analysis of lifetime performance and prolificacy in Landrace sows using a linear mixed model with censoring. Livest. Prod. Sci. 72:243-252.

Ikonen, T., K. Ahlfors, R. Kempe, M. Ojala, and O. Ruottinen. 1999a. Genetic parameters for the milk coagulation properties and prevalence of noncoagulating milk in Finnish dairy cows. J. Dairy Sci. 82:205-214.

Ikonen, T., S. Morri, A.-M. Tyrisevä, O. Ruottinen, and M. Ojala. 2004. Genetic and phenotypic correlations between milk coagulation properties, milk production traits, somatic cell count, casein content, and pH of milk. J. Dairy Sci. 87:458-467.

Ikonen, T., O. Ruottinen, E.-L. Syväoja, K. Saarinen, E. Pahkala, and M. Ojala. 1999b. Effect of milk coagulation properties of herd bulk milks on yield and composition of Emmental cheese. Agric. Food Sci. Finland 8:411-422.

ISTAT (Istituto Nazionale di Statistica). 2008. Sistema informativo su agricoltura e zootecnia. Accessed Dec. 16, 2009. http://agri. istat.it.

Kotsiantis, S., and D. Kanellopoulos. 2006. Discretization techniques: A recent survey. GESTS Int. Trans. Computer Sci. Eng. 32:47-58.

Le Bars, D., and J. C. Gripon. 1993. Hydrolysis of $\alpha_{\mathrm{s1}}$-casein by bovine plasmin. Lait 73:337-344.

Lindström, U. B., V. Antila, and J. Syväjärvi. 1984. A note on some genetic and non-genetic factors affecting clotting time of Ayrshire milk. Acta Agric. Scand. 34:349-355.

Lucey, J. A. 1996. Cheesemaking from grass based seasonal milk and problems associated with late-lactation milk. Int. J. Dairy Technol. 49:59-64

Malacarne, M., A. Summer, E. Fossa, P. Formaggioni, P. Franceschi, M. Pecorari, and P. Mariani. 2006. Composition, coagulation properties and Parmigiano-Reggiano cheese yield of Italian Brown and Italian Friesian herd milks. J. Dairy Res. 73:171-177.

McSweeney, P. L. H., N. F. Olson, P. F. Fox, A. Healy, and P. Højrup. 1993. Proteolytic specificity of plasmin on bovine $\alpha_{\mathrm{s} 1}$-casein. Food Biotechnol. 7:143-158.

Nielsen, S. S. 2003. Plasmin system in milk. Pages 924-934 in Encyclopedia of Dairy Sciences. Vol. 2. H. Roginski, J. W. Fuquay, P. F. Fox, ed. MPG Books Ltd., Bodmin, Cornwall, UK.

Okigbo, L. M., G. H. Richardson, R. J. Brown, and C. A. Ernstrom. 1985a. Effects of $\mathrm{pH}$, calcium chloride, and chymosin concentration on coagulation properties of abnormal and normal milk. J. Dairy Sci. 68:2527-2533.

Okigbo, L. M., G. H. Richardson, R. J. Brown, and C. A. Ernstrom. 1985b. Variation in coagulation properties of milk from individual cows. J. Dairy Sci. 68:822-828.

Oloffs, K., H. Schulte-Coerne, K. Pabst, and H. O. Gravert. 1992. Die Bedeutung der Proteinvarianten für genetische Unterschiede in der Käsereitauglichkeit der Milch. Züchtungskunde 64:20-26.
Pagnacco, G., and A. Caroli. 1987. Effect of casein and $\beta$-lactoglobulin genotypes on renneting properties of milks. J. Dairy Res. 54:479485

Politis, I., and K. F. Ng-Kwai-Hang. 1988. Effects of somatic cell counts and milk composition on the coagulating properties of milk. J. Dairy Sci. 71:1740-1746.

Raftery, A. E., and S. M. Lewis. 1992. How many iterations in the Gibbs Sampler? Pages 763-774 in Bayesian Statistics IV. J. M. Bernardo, J. O. Berger, A. P. Dawid, and A. F. M. Smith, ed. Oxford Univ. Press, New York, NY.

Samoré, A. B., C. Romani, A. Rossoni, E. Frigo, O. Pedron, and A. Bagnato. 2007. Genetic parameters for casein and urea content in the Italian Brown Swiss dairy cattle. Ital. J. Anim. Sci. 6(Suppl. 1):201-203.

Srinivasan, M., and J. A. Lucey. 2002. Effects of added plasmin on the formation and rheological properties of rennet-induced skim milk gels. J. Dairy Sci. 85:1070-1078.

Summer, A., P. Formaggioni, F. Tosi, E. Fossa, and P. Mariani. 1999 Effects of the hot-humid climate on rennet-coagulation properties of milk produced during summer of 1998 and relationship with the housing systems in the rearing of Italian Friesian cows. Ann. Fac. Med. Vet. Univ. Parma 19:167-179.

Tanner, M. A., and W. H. Wong. 1987. The calculation of posterior distributions by data augmentation. J. Am. Stat. Assoc. 82:528 550

Tyrisevä, A.-M., T. Ikonen, and M. Ojala. 2003. Repeatability estimates for milk coagulation traits and non-coagulation of milk in Finnish Ayrshire cows. J. Dairy Res. 70:91-98.

Tyrisevä, A.-M., S. Morri, T. Ikonen, O. Ruottinen, K. Saarinen, and M. Ojala. 2000. Genetic correlations between milk coagulation traits, casein content and milk production traits. Page 86 in Book of Abstracts of the 51st Annual Meeting of the European Association for Animal Production, The Hague, the Netherlands. Wageningen Academic Publishers, Wageningen, the Netherlands.

Tyrisevä, A.-M., T. Vahlsten, O. Ruottinen, and M. Ojala. 2004. Noncoagulation of milk in Finnish Ayrshire and Holstein-Friesian cows and effect of herds on milk coagulation ability. J. Dairy Sci. 87:3958-3966.

Wedholm, A., L. B. Larsen, H. Lindmark-Månsson, A. H. Karlsson, and A. Andrén. 2006. Effect of protein composition on the cheesemaking properties of milk from individual dairy cows. J. Dairy Sci. 89:3296-3305.

Zachos, T., I. Politis, R. C. Gorewit, and D. M. Barbano. 1992. Effect of mastitis on plasminogen activator activity of milk somatic cells. J. Dairy Res. 59:461-467. 